\title{
Facilitating consolidation and development of village unit cooperative business plan in Central Java
}

\author{
Agung Sudjatmoko ${ }^{a, 1, *}$, Adi Teguh Suprapto ${ }^{a, 2}$ \\ ${ }^{a}$ Universitas Bina Nusantara, Jl. K. H. Syahdan No 9 Kemanggisan/Palmerah, Jakarta Barat, DKI Jakarta 11480, Indonesia \\ 1 agung.sudjatmoko@binus.edu*; 2adi.suprapto@binus.edu \\ * Corresponding author
}

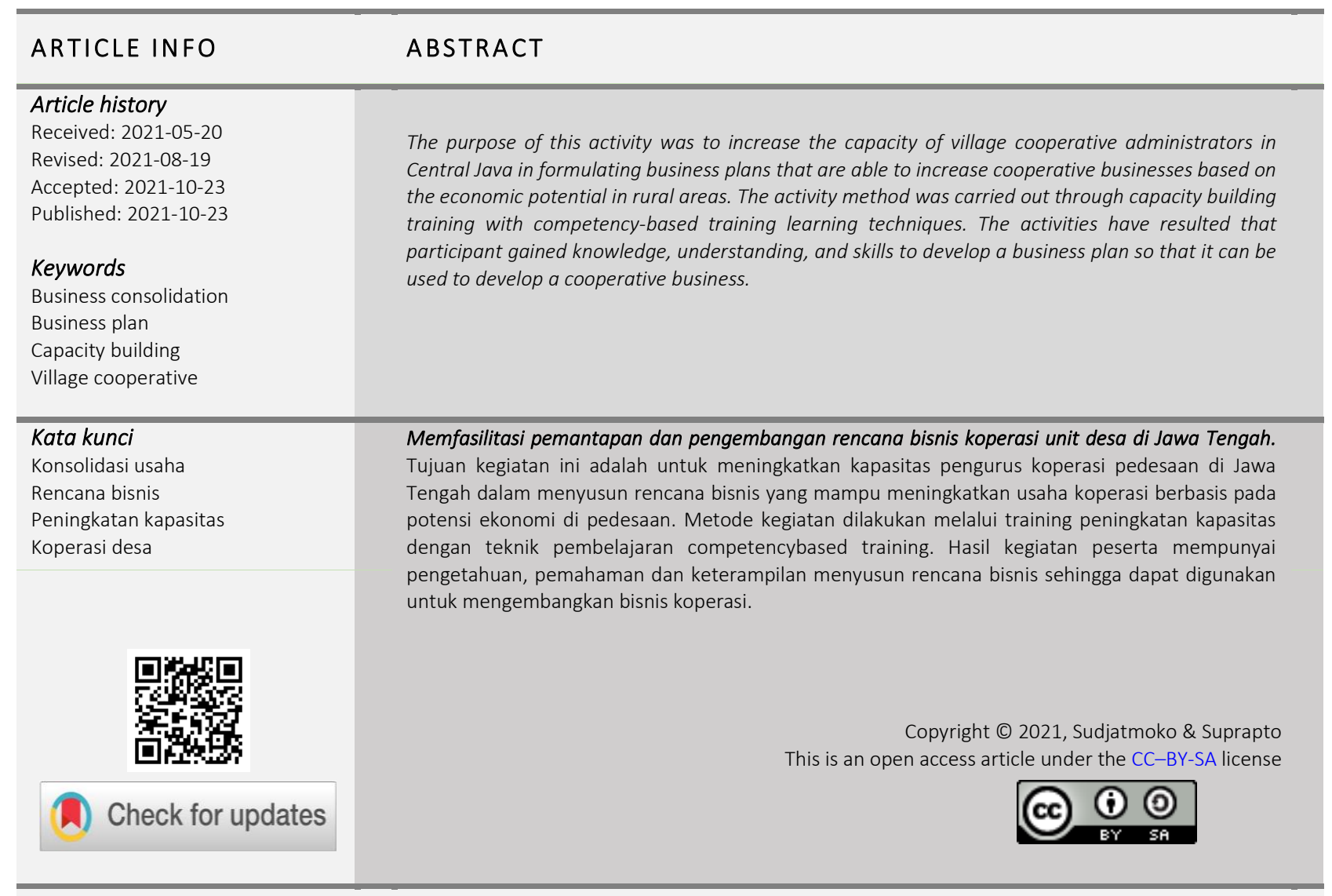

How to cite: Sudjatmoko, A., \& Suprapto, A. T. (2021). Facilitating consolidation and development of village unit cooperative business plan in Central Java. Journal of Community Service and Empowerment, 2(3), 127-132. https://doi.org/10.22219/jcse.v2i3.16576

\section{INTRODUCTION}

The existence of cooperative in Central Java shows good dynamics since the era of 70s during the New Order government led by President Suharto. The village cooperative, well-known as the Village Unit Cooperative (KUD) was successful because of government support, which focused on increasing agricultural production, especially rice. Thus, various programs to increase agricultural output are carried out using village cooperatives. The government's policy at that time gave the role on the cooperative sector to: a) distribute agricultural production facilities (saprotan), b) provide seeds needed by farmers, c) distribute subsidized fertilizers to farmers, and d) guarantee the purchase of farmers' production. This activity went well because there was good support from the government. Therefore, our country achieved food selfsufficiency, as until 1970s, there was high rate of food shortage and poverty. Finally, in 1984, our country received an award fro FAO for its ability to be a country with self-sufficient food. 
Hpwever, after the collapse of the New Order government and the change of government, the situation was reversed. Various government subsidies and facilitation for village cooperatives were revoked that caused cooperatives lose direction in running their business. On the other hand, farmers expect easy, affordable, and guaranteed production facilities. The loss of government alignment with agriculture, agriculture facilities in village cooperatives, and increasingly capitalistic business challenges, as well as reduced subsidies have had an impact on slowing down the village cooperative business and even some village cooperatives or KUD to collapse. This is due to the lack of government support and lack of capacity for village cooperatives administrators and managers.

The problems faced by village cooperatives or KUD is based on literature and field observations are found in the following aspects: a) the capacity of the management who lacks understanding of social and economic consolidation in cooperatives, b) compiling and implementing business plan, c) developing a modern management system, (d) applying information technology in cooperatives, and e) weak entrepreneurial skills that need to be improved.

The number of cooperatives in the nation until 2020 is 127,124 units, with the number of cooperatives that already have cooperative identification (NIK) as many as 38,865 . The number of cooperative members nationally is also quite large, namely $25,098,807$ people or about $9 \%$ of the current population. The number of cooperatives in Central Java is 12,190 units, with the number of village cooperatives per 2020, as many as 567 units spread over 35 regencies/cities. Of this number, the village cooperative units (KUD) that held annual member meeting (RAT) showed that the cooperative still had activities as many as 333 units or $58.73 \%$. The number of cooperatives that participated in this activity were 60 village cooperatives consisting of KUD and multipurpose cooperative (KSU) from Solo City, Karanganyar Regency, Klaten Regency, Boyolali Regency, Pati Regency, Wonogiri Regency, and Sukoharjo Regency. According to the above conditions, community service activities were carried out in cooperation with Indonesian Cooperative Council (Dekopin). This activity has contributed in increasing the capacity of cooperative management in analyzing business opportunities, formulating business plans and developing collaboration or cooperation with various other stakeholders.

Cooperatives are companies that have a goal to realize the common welfare of its members. Conceptually, cooperatives are a form of business entity owned by members and at the same time make members as the users or customers of the business run by the cooperatives. Hanel (2005) asserts that the role of members in cooperative is as the owner as well as customers, the dual role in cooperatives is a system pf social and economic consolidation simultaneously so that the size and progress of the cooperative is determined by the active participation of members in the field of organization and business. Members as owners are obliged to develop cooperatives by contributing and actively participating in every policy making and cooperative program, fulfilling obligation, and having a high concern for the growth and development of cooperatives. Meanwhile, as users, members have the obligation to use the service of their cooperative business and are entitled to get good service in meeting their needs. To realize their roles and functions as well as their rights and obligations, members must actively participate by participating in activities carried out by cooperatives. In other words, members are required to actively participate in every cooperative activity to realize mutual prosperity in accordance with the identity of the cooperative. This is in line with the opinion of Hendar and Kusnadi (2002:76) who state that the most important factor in supporting the success or development of an organization is participation.

In organization rule, the highest decision-making for cooperatives is at the members' meeting. Members' meeting are attended by members to discuss and decide on work program planes, organizational and membership policies, business developments and plans, as well as various other cooperative strategic decisions. The implementation of business management in cooperatives is carried out by the management assisted by management called employees who work under a work contract with the cooperative. Management in cooperatives only works in cooperatives to help plan, manage, develop cooperative businesses but do not have the right to make organizational decisions. They are professionals who work and are paid according to the contract or regulations in the cooperative.

Cooperative business is based on efforts to meet economic, social, and member interests or needs, so cooperatives are companies that seek to provide services to members so that the business function of cooperatives is product or service efficiency to gain profits or surpluses. This is in accordance with the understanding of cooperatives according to ICA (1995) that cooperatives are associations of individual members who have socio-economic interests of members and establish cooperative companies that are controlled democratically. This means that a cooperative is a company, which is oriented to meet the needs of its members, the basis of its business is efficiency and effectiveness, with an appropriate economy of scale so as to provide welfare to members. Jones and Kalmi's (2015) research on cooperative banks in Finland, states that a positive relationship between membership and performance in financial cooperatives is consistently found (Jones \& Kalmi, 2015). Sebhatu et al's (2021) research on village unit cooperatives in northern Ethiopia, underscores the importance of member size, total assets, and conflict between members and unions on the performance of a cooperative (Sebhatu et al., 2021).

Veronica et al's research in Spain (2021), explains the role of cooperatives, where most of the owners of agricultural land are currently decreasing due to changing professions and moving to cities. As a result, agricultural production declines and supply decreases. Cooperatives innovate by acting as organizers of mutual cooperation between land owners and farm workers so that the land can remain productive, and the supply of agricultural products can increase (Veronica et al., 2021). Meanwhile, Sultana et al's (2020) research on cow's milk farmer cooperatives in Bangladesh found that it does not last long or is not sustainable. Cooperatives ensure a safe market for farmers' produce at reasonable prices and provide technical assistance through training and extension that leads to higher production and higher incomes for farmers. Motivated farmers show positive behavior towards the community in the long term. These conditions can help to maintain community cooperatives in other sectors of agriculture in Bangladesh. Therefore, interventions should be taken to strengthen and 
expand sustainable agricultural cooperatives in all sectors of Bangladesh (Sultana et al., 2020). Rahmana et al's (2020) research is on how cooperatives can mediate entrepreneurial orientation to become entrepreneurs. Thus, cooperatives can persuade their members to become entrepreneurs so that they can contribute to economic growth (Rahmana et al., 2020).

The purpose of this activity was to increase the capacity of village cooperative administrators in Central Java in formulating business plans that are able to increase cooperative businesses based on the economic potential in rural areas.

\section{METHOD}

The method implemented in this community service activities was carried out by providing training, mentoring, and consultation, through education and training using systematic learning techniques to increase the competency capacity of village cooperative administrators through lecture and discussion techniques, mentoring and consultation to develop a strategy for consolidation of cooperative businesses and the cooperative business plan carried out will be carried out by the village cooperative. Therefore, village cooperatives have the ability to bounce back, make changes to business strategies, strengthen member-based businesses, and become trusted business actors, and have good competitiveness. The training methodology used a competency-based training approach, which prioritizes brainstorming with participant experience. Meanwhile, the training technique used brainstorming (brainstorming), question and answer, lectures, and practice.

\section{RESULTS AND DISCUSSION}

The implementation of the activities is carried out systematically and practically, because the participants come from the region and already have experience and are of mature age. To achieve maximum results, the stages of implementing the activity are carried out using the following stages: 1) Preparation, carried out by a team in collaboration with the Indonesian Cooperative Council (DEKOPIN) which invites researchers to be involved in this activity. Dekopin invites participants from village cooperatives that are potential to be developed. The criteria for invited cooperatives are that their businesses and organizations are still running well, the potential for regional agriculture is quite a lot, their human resources still have the potential to progress, and they still have networks with various parties. 2) Implementation, at this stage, activities are carried out focusing on providing training to participants on cooperative business consolidation strategies and how to prepare realistic business plans that can be used as guidelines for cooperative management participants in developing cooperative businesses based on local potential. 3) Evaluation, in this section an evaluation of the implementation of the activities is carried out, both the objectives, results, and problems that exist during the activity, so that researchers get input on the implementation of activities to improve future activities. Finally, the last is stage 4) Followup, which is an activity to follow up on various results that will be carried out by village cooperatives so that there is a follow-up activity plan to guide village cooperatives to develop their organizations and businesses.

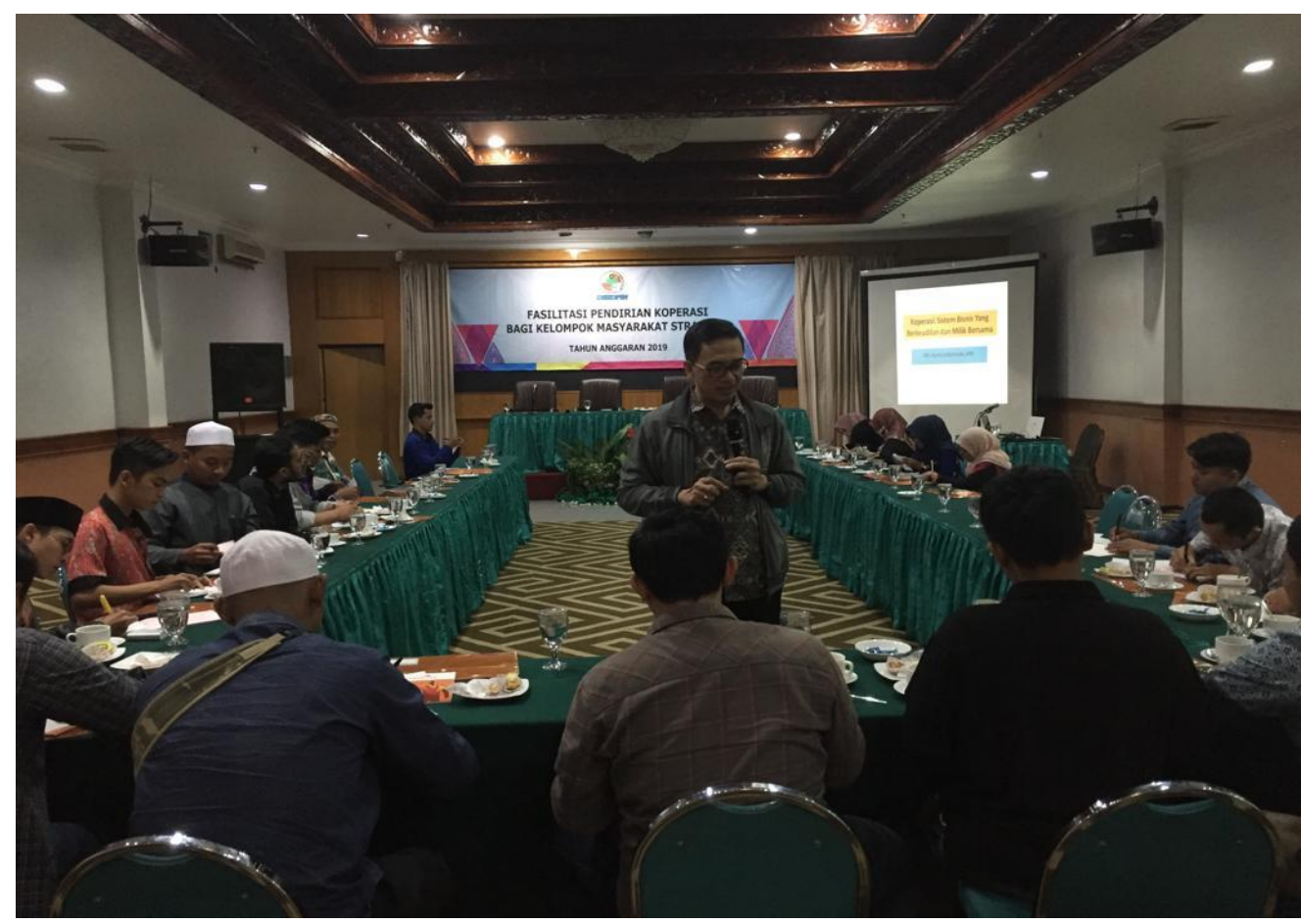

Figure 1. Activities on education and training for village cooperative management 
Training to increase the capacity of cooperative management is carried out using lecture techniques, question and answer, case studies, and analysis of work practices that have been carried out by participants. Cooperative business consolidation is a combination of social and economic consolidation. Meanwhile, social consolidation is the embodiment of cooperatives as an association of people, not a collection of capital so that the number, similarity of economic needs/interests, economic capacity, and diversity become the basic capital of cooperatives for the unification of interests. This must be supported by economic consolidation because the needs of the assembled members are an economic market that must be met. As a social and economic consolidation, the management of cooperatives must use the principles and values of cooperatives, and a management system that is in accordance with modern and professional enterprise economic principles.

Cooperatives are companies that must be managed properly to build member trust. Member trust will increase member participation in developing cooperatives, and cooperative development will provide welfare to members. This consolidation is not only limited to meeting the economic needs of members in the consumption aspect but also in the production aspect. The cooperative business must be related to the member business. The basic principle of a cooperative is that members submit their business affairs to the cooperative because it can be managed efficiently as it is based on togetherness and cooperation. If the cooperative is managed individually, it will not be efficient. Efficiency, effectiveness, togetherness, and business consolidation in cooperatives is what develops cooperatives. If this is described, the structure is described as in the image below.

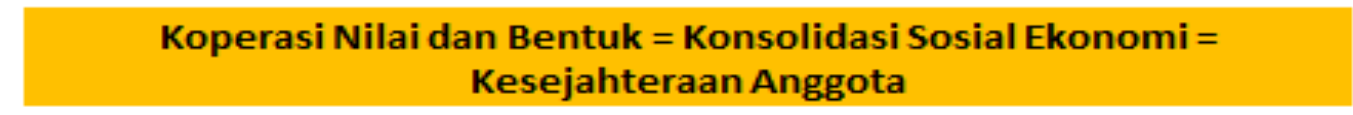

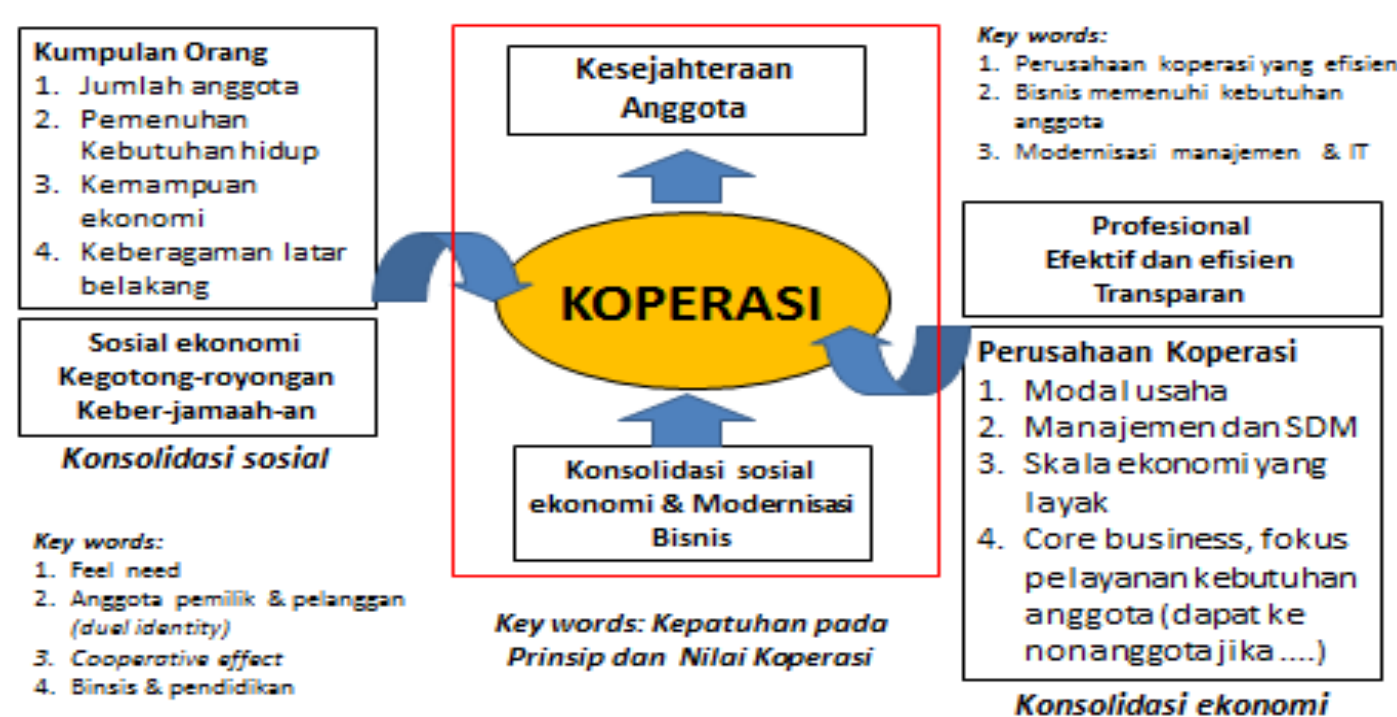

Figure 2. Cooperative social and economic consolidation of members for welfare

This cooperative business consolidation training provides participants with an understanding that developing cooperatives has multidimensional aspects, first, it is on the aspect of social consolidation, namely: a) Building the strength of mutual cooperation among all members of the cooperative; b) The role of members is very central in developing cooperatives because members are owners as well as customers of cooperative businesses; c) The existence of cooperatives must provide concrete economic and social effects felt by members, member transactions are faster, cheaper and easier than other business actors. Surplus results of cooperative operations are distributed according to the volume of transactions between members and their cooperatives; d) Cooperatives are companies that must build their business in accordance with the business interests of members. Productivity of members and economic access of members of the cooperative must be built synergistically. Cooperatives have a role to support members' business activities, for reasons of business efficiency and effectiveness.

The second is the aspect of economic consolidation that cooperatives as businesses must be able to: a) Become an efficient company so that it can help provide optimal services to members, to become an efficient business actor, cooperative management must be managed in accordance with the company's economic principles based on economies of scale and feasibility; b) Building a business for the benefit of members based on the scale of business feasibility and focusing on the business of serving the needs of members; Cooperatives must build independent capital to realize selfsufficiency and low-cost financing; c) Cooperative business must be managed using modern management and IT systems to achieve transparency, credibility, and management accountability that builds member trust. 
Furthermore, the third is the aspect of management which is also important, because this aspect determines the good or bad of a cooperative. This aspect contains elements of organizational management, organizational structure, organizational culture, leadership, organizational support infrastructure, and the physical environment available in cooperatives. Aspects of cooperative management are closely related to cooperative compliance in carrying out cooperative principles and values. The cooperative principle is a model of a democratic economic system and provides equal opportunities to all members to build their economic and social productivity. The cooperative principle that is carried out seriously and consistently does not conflict with the prevailing economic principles, in fact this cooperative principle will build the strength of the cooperative as an inclusive economic actor for the togetherness and economic unity of its members.

This activity also provided an understanding of the strategy of preparing a business plan for cooperative management. As a guideline for running a business, business planning is very important. The system for preparing business plans is carried out by implementing learning techniques using working papers so that participants are immediately invited to think, discuss, and work on filling out the prepared working papers. The prepared working papers are in accordance with the business plan format. Thus, participants immediately learn, discuss, and ask questions if there are problems during the learning process. Some aspects that can be obtained from the training system with direct practice of business planning are: a) Members easily understand about business plans including background, objectives, benefits, and the systematics and content of work plans for village cooperatives, b) Participants understand that making business plans does not only look at internal factors, as external factors also contribute to formulating a comprehensive business plan, which can be carried out in accordance with the objectives and targets of the business to be carried out; and c) The business plan as a guideline for business development must have a vision, mission, and goals to be achieved by the cooperative in a certain period, because of that the stages of realizing business development must be carried out.

In regards of series of activities that have been carried out after being evaluated, participants understand more about the cooperative business development strategy. In addition, the researchers also received an input on various problems, especially tax issues and how the management of village cooperatives maintained the cooperative business in the past and the present era. They even hope to receive follow-up activities, such as training and assistance in modernizing the cooperative's business, building and expanding business networks as well as quality development activities for cooperative managers.

\section{CONCLUSION}

The facilitation activities for the consolidation of cooperative businesses and the preparation of business plans are real activities to help the management of village cooperatives maintain and develop their businesses. Various problems of organization and business of village cooperatives can be raised, discussed, and solved its problems by reviewing theory or sharing experiences with other participants. Thus, this activity in addition to increasing the insight of the management also encourages the motivation of the management of village cooperatives to be redeveloped. In a slowing macroeconomic situation with large business opportunities in the natural resource processing sector, especially rural agriculture, village cooperatives can carry out this role if given the opportunity to return and is facilitated by various parties, so that village cooperatives are able to rise again to develop the agricultural sector. The government's support is needed to create a conducive atmosphere for the opening of access to capital, technology, marketing, and the role of village cooperatives in realizing community independence.

Based on the entire series of activities and dynamics that occur through interaction with participants, the following suggestions can be formulated: 1) Village cooperatives are still ready to develop the potential in rural areas, particularly to develop agriculture that is capable of realizing national food independence. The agricultural, plantation, fishery, and forestry sectors are sectors that can be driven by cooperatives because the role of cooperatives is to be a forum for members/communities to create a mutual cooperation economic system for the people's economic independence. Meanwhile, the government has a role to provide incentives to village cooperatives that will develop businesses in the sector, 2) The problems that occur in village cooperatives can be resolved if the management of cooperatives returns to their cooperative identity, conducts social and economic consolidation, builds member trust, increases the number and participation of members, as well as modernizing management and utilizing information technology, and 3) The development of current and future cooperatives requires a business plan that meets the business feasibility criteria and the goals to be achieved in the future by the cooperative.

Gratitude is conveyed to DEKOPIN for providing the opportunity as well as preparing the funding so that this activity runs well. To the management of the participating cooperatives, we also express our gratitude for continuing to work to optimize the business in their respective cooperatives. 


\section{REFERENCES}

Ariestantia, W., \& Achdiat, Y. (2014). Pengaruh kualitas pelayanan terhadap partisipasi anggota serta implikasinya terhadap keberhasilan koperasi. Portal Jurnal UPI. http://jurnal.upi.edu/4023/view/1092/pengaruh-kualitaspelayanan-terhadap-partisipasi-anggota-serta-implikasinya-terhadap-keberhasilan-koperasi.html

Hadayati, N., Rifki, H., \& Pradesa, H. A. (2016). The influence of service quality and sense of belonging toward members' participation in co-operative enterprise. Journal of Business and Management (IOSR-JBM), 18, 55-65.

Hanel, A. (2005). Organisasi koperasi. pokok-pokok pikiran mengenai organisasi koperasi dan kebijakan pengembangannya di negara-negara berkembang. Yogyakarta: Graha Ilmu.

Hatta, M. (2005). Membangun koperasi dan koperasi membangun (Edisi kedua). Jakarta: Inti Idayu Press.

Hatta, M. (2015). Membangun koperasi dan koperasi membangun. Jakarta: PT. Kompas Media Nusantara.

Ropke, J. (2003). Ekonomi koperasi teori dan manajemen. (S. Djatnika, Penerjemah) Jakarta: Salemba Empat.

Jones, D., \& Kalmi, P. (2015). Membership and performance in finnish financial cooperatives: A new view of cooperatives? Review of Social Economy, 73(3), 283-309. https://doi.org/10.1080/00346764.2015.1067753

Rahmana, F., Sudjatmoko, A., \& Farmania, A. (2020). The role of cooperative mediation in increasing the number of entrepreneurs: Case study of the DKI credit cooperative. Management Science Letters, 10(6), 1241-1250. https://doi.org/10.5267/j.msl.2019.11.034

Sebhatu, K. T., Gezahegn, T. W., Berhanu, T., Maertens, M., Van Passel, S., \& D’Haese, M. (2021). Exploring variability across cooperatives: Economic performance of agricultural cooperatives in northern Ethiopia. International Food and Agribusiness Management Review, 24(3), 397-419. https://doi.org/10.22434/IFAMR2019.0215

Sultana, M., Ahmed, J. U., \& Shiratake, Y. (2020). Sustainable conditions of agriculture cooperative with a case study of dairy cooperative of Sirajgonj District in Bangladesh. Journal of Co-Operative Organization and Management, 8(1), 100105. https://doi.org/10.1016/j.jcom.2019.100105

Veronica, P., Victor, M. G., Elena, M. M., \& Jose-Maria, G. A. C. (2021). Drivers of joint cropland management strategies in agri-food cooperatives. Journal of Rural Studies, 84, 162-173. https://doi.org/10.1016/j.jrurstud.2021.04.003 